\title{
Author Correction: Dynamic responses of the haematopoietic stem cell niche to diverse stresses
}

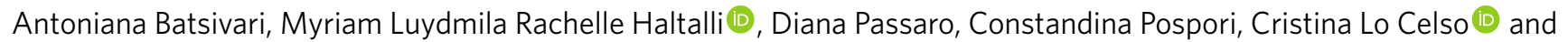
Dominique Bonnet (1)

Correction to Nature Cell Biology https://doi.org/10.1038/s41556-019-0444-9, published online 6 January 2020

In the version of this Review Article originally published, the name of co-author Myriam Luydmila Rachelle Haltalli was spelled incorrectly. The error has been corrected in the HTML and PDF versions of the paper.

Published online: 22 January 2020

https://doi.org/10.1038/s41556-020-0469-0

(c) Springer Nature Limited 2020

\section{Publisher Correction: STRIPAK integrates upstream signals to initiate the Hippo kinase cascade}

Rui Chen, Ruiling Xie (D), Zhipeng Meng, Shenghong Ma D and Kun-Liang Guan (D)

Correction to Nature Cell Biology https://doi.org/10.1038/s41556-019-0426-y, published online 2 December 2019

In the version of this article originally published, the plus and minus conditions of serum in Fig. 1c were swapped. It should be ' -+-+ instead of ' +-+- . The error has been corrected in the HTML and PDF versions of the paper.

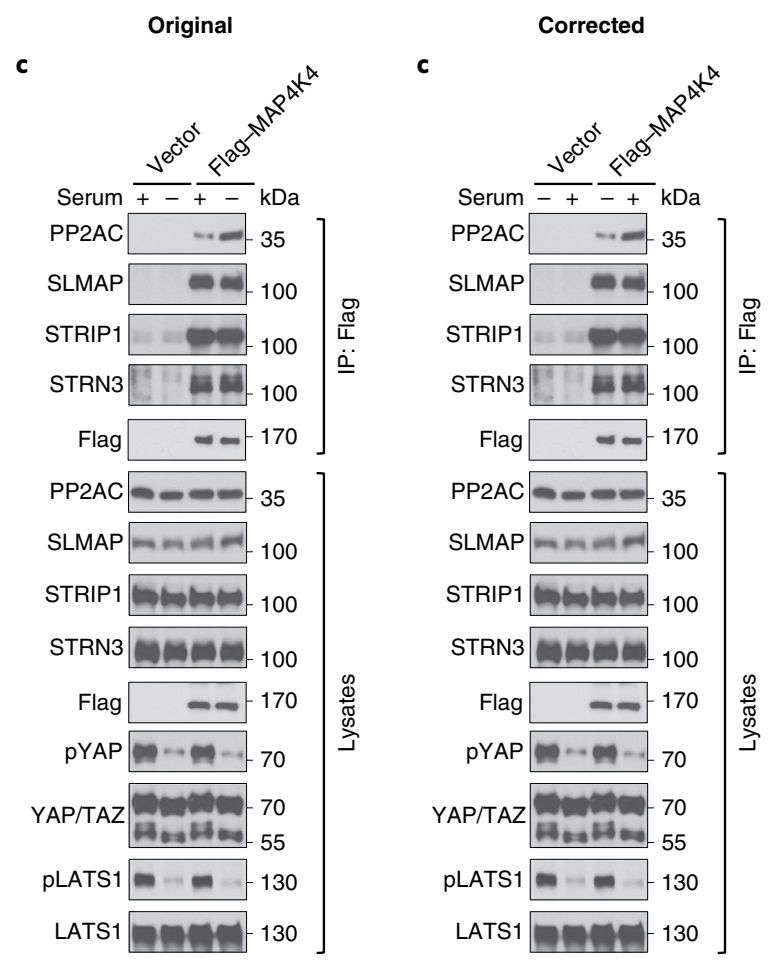

Fig. 1c | Original and Corrected.

Published online: 2 January 2020

https://doi.org/10.1038/s41556-019-0460-9

(C) The Author(s), under exclusive licence to Springer Nature Limited 2020 